\title{
DIE VERBONDELING IN VERBAND
}

Daar is dikwels en deur groot outoriteite al geskryf oor die mens in die samelewing. Hier wil ons egter die saak probeer aanraak uit 'n nuwe hoek, veral om die Skrifbeligting van die siening te benader. Vanselfsprekend verg hierdie benaming 'n skrifmatige mensbeskouing, maar ook 'n skrifmatige verbandsbeskouing. Die mens staan egter nie slegs in verhouding tot sy medemens nie maar ook in verhouding tot stof, plant en dier. Boweal staan die mens in verhouding tot God, en hierdie verhouding is deurslaggewend vir al die ander verhoudinge waarin die mens hom bevind. Tog staan die mens ook in verhouding tot homself; wie kan die diepere roersele van die menslike siel peil, wie weet van die wroeginge, vreugde, leed en genot van die mens beter as hyself? Ook hierdie aspek verdien ons aandag. Op volledigheid kan nie aanspraak gemaak word nie, dit is ook nie my bedoeling nie. Die bedoeling is maar om die omvang van die tema aan te dui, die gedagtes te prikkel en veral om aan te spoor tot nuwe denkoriëntering waarin ook terminologies gebreek behoort te word met die neo-skolastiek binne reformatoriese lyn.

\section{Die verbondeling:}

Wie is die verbondeling? Dit is die mens: die mens voor die sondeval maar ook die na-sondevalse mens en dan, nader bepaald, die uitverkore mens. Ons noem die mens verbondeling om hom sodoende skerp te onderskei van die res van die aardse skepping nl. stof, plant en dier. Ons noem die mens verbondeling - juis omdat God gesê het: Laat ons mense maak na ons beeld en na ons gelykenis. Ons noem die mens verbondeling omdat hy beelddraer is van God. Ons noem hom verbondeling omdat hierdie skeppingsaard van die mens daarop dui dat die mens kind van God is. Hy is kind van God omdat God hom na sy beeld geskape het. Die mens is 'n heel besondere skepsel: hy is kind van die Vader omdat God hom in 'n Vader-kindverhouding geskape het. Hierdie Vaderkind-, kind-Vaderverhouding noem ons die verbond tussen God en die mens, 'n verbond komende van God waarin die 
mens geen seggenskap gehad het of het nie. God staan tot die res van die aardse skepping in 'n ander verhouding as tot die mens. God staan tot die hele aardse skepping in 'n Skepper-skepping verhouding. Slegs by die mens is hierdie verhouding, kragtens die Skepperswil van God, 'n wederkerige verhouding: slegs die mens van alle aardse skepsele, staan ook in 'n regstreekse relasie tot die Skepper: die kindVader-relasie. Hierdie wedersydse relasie waarin God Homself tot die mens en die mens tot Hom gestel het met die skepping van die mens, dui ons aan met die term "religie". Ons benoem die mens derhalue in die diepste van sy menswees as ons hom 'n religieuse wese noem. Maar hierdie mens het God gemaak uit die stof van die aarde en in sy neusgate het $\mathrm{Hy}$ die asem van die lewe geblaas. Die mens is derhalwe uit die aarde, aards. Hy het deel aan alles wat deur God geskape is: alles wat in die ander drie ryke voorkom, tref ons ook by die mens aan. En tog is die mens anders as stof, plant en dier. Hy is 'n religieuse wese. Hierin lê die ooreenstemming maar veral ook die verskil tussen die mens en die res. Die mens is verbondeling! En as die mens die kindVader-relasie verbreek, in sonde val, dan vervloek God die hele aardse skepping. Ook stof, plant en dier word hierdeur getref - so handhaaf God in die gevalle wêreld weer die harmonie en verskeur God nie die mens, in die sin dat dit wat hy gemeenskaplik, maar anders, met stof, plant en dier besit, nie deur die sonde getref word nie. En die verlossing en herskepping bevestig hierdie relasie, want deur die Tweede Adam word ook weer die res van die skepping van hierdie sondevlek rein gewas. So staan alleen die mens in regstreekse relasie tot God. So staan stof, plant en dier via die mens in relasie tot God.

As die klem by ons val op die verbondeling, dan wil ons in die eerste plek daarmee aandui die verhouding tussen God en die mens en tussen die mens en God. Dan is dit egter ook duidelik dat ons hier met die besondere mens te doen het, met die enkeling, as $u$ wil: met Adam as Adam, met Eva as Eva, met my as enkeling, met $u$ as enkeling, met hom wat God geken het van voor die grondlegging van die wêreld af, met $u$ en met my wat persoonlik verantwoording aan God verskuldig is! Vandaar ons standpunt dat die mens as sodanig 'n religieuse wese is! Hierdie belangrike waarheid in verband met ons menswees mag nie uit die oog verloor word nie. Elke 
mens is onverganklik in dié sin dat hy geskape is om nie te sterf nie, om nie vernietig te word of te vergaan soos stof, plant en dier nie: hy sal die koninkryk beërue of die ewige verdoemenis ingaan. Selfs al sterf hy die tweede dood word hy nie vernietig nie - en hierin lê die verskrikking van die sonde. Die sonde het egter via Satan sy intrede in die aardse skepping gemaak. En hierdie sonde het gekom deurdat die mens daartoe verlei is om te wil wees soos God is: om God te wil wees. Hierdeur het die mens, as gevolg van sy ongehoorsaamheid aan die gebod van God, as gevolg van sy wetsoortreding, die kind-Vader-verhouding verbreek en in 'n afvallige rigting tot God te staan gekom. Die mens bly 'n religieuse wese, maar nou vertoon die struktuur van die religie 'n tweërlei karakter: die afvallige het daarby gekom! Die verbondeling het nou verbondsverbreker geword en sodoende algeheel verdorwe geraak. Omdat hy van die begin af geen sê in sy verbondelingskap gehad het nie, het hy ook nou geen seggenskap in die herstel van die verbondsverhouding nie. Dit kan alleen herstel word deur Jesus Christus: alleen deur die soendood van Christus, die vleesgeworde Woord, kan die afvallige mens weer 'n kind van God gemaak word. Om die kind-Vader-relasie te herstel, is die genade van God nodig: verlossende genade wat direk na die sondeval in werking getree het. Vandaar die Skrifwoord: Niemand kom tot die Vader behalwe deur My nie. En hierdie verlossing is niks anders as vrymaking van die slawebande van die sonde nie. Vandaar dat Christelike vryheid niks anders beteken as vrymaking van sonde nie: die herstel van die kind-Vader-verhouding. Maar dan nie 'n terugkeer tot die voorsondevalse staat nie: die mens, die vrygekoopte mens het deur die sonde heengegaan. Om hierdie rede veronderstel die begrip vryheid m.i. in 'n skrifmatige denke die sondeval en behoort vryheid nie tot die oorspronklike toerusting van die mens nie: die voorsondevalse mens was goed, ja baie goed, hy was die gehoorsame mens, die mens wat in 'n positiewe verhouding tot die gebod van God gelewe het: „Wie die Midd'laar se verskyning inwag uit die heiligdom, soek van harte die verreining wat daar uit sy sterwe kom. Teen die sonde duur die stryd: sonde is ongeregtigheid! Maar ons lewe uit God gebore, is tot heiligwees verkore" (Skrifberyming $33: 3$ ). So staan die na-sondevalse mens of in ' $n$ herstelde verbondsrelasie tot God, ò in ' $n$ afvallige relasie tot God: sy hart is deur die uitverkiesende genade deur 
die soenverdienste van Christus en die genadige leiding van die Heilige Gees weer tot God gerig, of dit is in afvalligheid van God afgewend. Die mens as religicuse wese kan dus 'n herstelde verbondeling wees na die sondeval of 'n afvallige wat in die sonde bly lê het. Die verbondsrelasie waarin die mens tot God staan, is juis omdat dit die menswees tipeer, grondleggend vir al sy doen en late: die verhouding waarin die mens tot God staan bepaal alles wat uit hierdie mens ten opsigte van sy aardse bestaan voortkom. Alles wat die mens derhalwe doen, is religieus bepaald. Vandaar die motivering van die eerste vraag wat in 'n skrifmatige wysbegeerte aan elke denker gevra word: watter soort hart het jy? Of, in die woorde van D. H. Th. Vollenhoven: Wat maak jy met die Skrif? En as die hart van die mens reg is, sal hy as herstelde verbondeling weer dic wet van God gehoorsaam: dit was en bly die oorspronklike vereiste waaraan die verbond gekenmerk word. Hierdie wet noem Christus die liefdeswet, die wet met sy een gebod wat wys op die liefde tot God en sy tweede gebod wat uys op die selfliefde en die naasteliefde.

Vandaar ons standpunt dat die liefdeswet geld vir die volledige mens of soos die Skrif dit dikwels stel: vir die hart. Die verbondeling is verbondeling omdat hy deur die genade weer in die kind-Vader-relasie geplaas is as gevolg van Christus se vervulling van die wet. Die verbondeling is vrygemaak van die sonde, is weer in staat gestel om die wet te gehoorsaam, is vrygemaak tot gehoorsaming van die wet. Maar vir hierdie bedeling geld: „as ek die goeic wil doen, staan die kwaaie my by". Tog behoort dit só te wees: „ek leef nie meer nie maar Christus leef in my". Die woorde van 'n Sokrates is, in hierdic lig gesien, vir elke mens en elke denker van die grootste belang: Ken uself. Dit wil sê: weet wat die rigting van jou hart is, want die rigting van jou hart is grondleggend vir jou hele menswees; dus vir die volvoering van jou roeping op aarde, vir jou werk as heerser en beheerser van die hele aardse skepping. Dit maak van die verbondeling 'n nederige wese dit laat hom besef hoe swak hy is as profeet, priester en koning. Dit mak van hom 'n verantwoordelike wese, want hy is geroepe tot taakvervulling, 'n taak deur sy Vader hom opgelê. Dit maak ook van hom 'n magtige wese, want hy is kind van die Vader: heerser oor homself en die aardse skepping: „Wat is die mens dan dat $U$ hom gedenk het, die mensekind wat $U$ so ryk beskenk het! Met eer en heerlikheid is hy 
gekroon, skaars minder as die eng'le om u troon" (Psalm $8: 4$ ).

Hierdie verbondeling is ' $n$ aardsgeskape skepsel: sy tuiste is die aarde, sy taak is op die aarde. As verbondeling staan vir hom voorop sy kindwees van die Vader, sy gehoorsaming aan die wet van God: die eer en verheerliking van God; die uitbreiding van die koninkryk van God. Die verbondeling staan nou alreeds binne die koninkryk van God, en hierdie koninkryk eis hom ten volle op. Sy volle menswees moet aan hierdie diens gewy wees. Tog vertoon die koninkryk van God baie fasette: wie kan die rykdom hiervan peil? Een van hierdie fasette in die huidige bedeling is die lewe binne diẹ gemeenskap van mense, binne die samelewing. Vandaar dat ons praat van die verbondeling in verbandslewe. Juis hierdie verbandslewe het ons uitgekies vir nadere ondersoek. Onthou moet word dat ons hierdie verbandslewe waarin die verbondeling hom bevind, sien as een van die fasette van die koninkryk van God: hulle derhalwe sien as Christelike samelewingsverbande. Die verbondeling in die hiernamaalse nuwe aarde sal in die slotgedeelte nader belig word.

\section{Die verbondeling in verband:}

Die verloste, van sonde vrygemaakte, die vrye mens, die verbondeling staan binne die koninkryk van God in roepingsbewuste taakvervulling met verantwoordelikheid aan die Vader vir sy doen en late. Hy staan hier as profeet, priester en koning binne die koninkryk, en alles wat hy hier is en doen staan onder die vleuels van die Vader-kind, kind-Vaderverhouding; is religieus bepaald maar nou positief in 'n regse rigting van sy hart. Daarom moet alles hier geskied tot eer en verheerliking van God: uit Hom, deur Hom en tot Hom is alles.

Maar van hierdie verbondeling sê God in die begin: „dit is nie goed dat die mens alleen is nie, Ek sal vir hom 'n hulp maak". Adam is eerste gemaak en Adam is as verbondskind geskape. Maar God sê ook: „Laat Ons mense maak na ons beeld en ons gelykenis. En God het die mens gemaak, man en vrou het God hulle gemaak". Dit is dus duidelik dat die mens nie alleen in die Vader-kind-, kind-Vader-relasie staan nie, dit is ook duidelik dat die mens ook nie slegs alleen staan in sy verhouding tot homself en tot stof, plant en dier nie, maar die mens staan ook in verhouding tot sy medemens 
Hierdie verhouding is egter nie primêr of die eerste of belangrikste verhouding nie. Sommige eksistensialisties denkende persone wil beweer dat die mens eers mens word in sy medemenslikheid. Hulle vergeet die eie persoonlike verantwoordelikheid van die enkeling teenoor God en die persoonlike Vader-kind-, kind-Vader-verhouding; die verbondeling-wees van die mens. Vir hulle is die menswees afhankliklik van die medemenswees. En hiermee bedoel hulle nie die genetiese verband nie - wat hulle bedoel is gegee voor die genetiese verband: die medemenslikheid is grondleggend vir die menswees van die mens. Vir hulle is die menswees afhanklik van die medemenswees. Vir hulle verdwyn die verbondelingwees eintlik en hulle sien slegs die verbandswese raak. Dit is eensydig en buite clie Skrifbeligting.

Die verbondeling staan in sy persoonlike hoedanigheid binne die koninkryk van God en is hier geroepe tot die volle ontplooiing van sy ryk geskakeerde lewe. Een faset van die lewe binne die koninkryk van God is die verbandslewe. Die verbondeling het dus 'n roeping en taakvervulling ook in die verbandslewe van die koninkryk. Hy leef saam met ander verbondelinge binne die koninkryk van God. Hoe moet ons hierdie saamlewe nou verstaan sonder om geweld aan die verbondelingwees van die kind van God te doen; sonder om sy individualiteit te loën deur hom slegs te sien as verbandswese?

Om hier tot groter helderheid te kom, maak ons dankbaar gebruik van die modaliteitsleer van die Calvinistiese wysbcgeerte. Die menslike struktuur vertoon ook hier 'n rykdom van fasette wat die lewe in die verbande moontlik maak. God het die mens met sy skepping hiermee toegerus, dit behoort derhalwe tot die skeppingstoerusting van die mens. By Adam en Eva was hierdie toerusting ten volle en menslik volmaak ontplooi direk met hulle skepping, omdat hulle as voluassenes geskape is. By die mense daarna is hierdie toerusting ook gegee maar kom dit geleidelik tot ontplooiing in die proses van opvoeding en ontwikkeling en hang die ontplooiing daarvan af van die beskawingspeil van die milieu waarin die mens gebore word. Ons hoef hieroor nie breedvoerig uit te wei nie: genoeg dat ons besef dat die verbondeling sodanige toerusting besit, sodat hy in alle aspekte van sy lewe vir die uitvoering van sy deur God opgelegde taak sy roeping as mens kan vervul binne die rykgeskakeerde koninkryk van God, dus ook in sy 
verbandslewe. En die verbandslewe waartoe die mens geroepe is vertoon ' $n$ ander struktuur as die gewone mens-tot-mens verhouding. Ook sodanige verhoudinge bestaan en ook vir hulle geld die liefdeswet: jy moet jou naaste liefhê soos jouself. Hierdie naaste wat jy moet liefhê impliseer 'n medegelowige wat saam met jou binne die koninkryk van God lewe. Ook hy, net soos jy, moet beelddraer Gods wees, moet verloste kind van God wees, moet vry van die sonde wees. Dit geld derhalwe nie van hom wat in die sonde bly lê nie, dit geld nie van hom wat voortgaan met Satansdiens nie. Van sodanige persoon eis die wet dat jy hom in gehoorsaming aan die liefdeswet, moet haat: haat diegene wat My haat. Maar dan eis dieselfde wet dat jy ook jouself moet haat vir soverre jy nog in die sonde bly leef, asook jou naaste. Vir soverre jy en jou naaste binne die koninkryk van God nog nie die beeld van God vertoon nie, moet jy jouself en jou naaste haat. Hoe meer ek verlos word van die sonde, hoe voller word die beeld van God in my. Dieselfde geld van my naaste. Hoe meer ck verlos word van die sonde hoe beter is die kind-Vader-relasie herstel. Hieraan moet die eie en naasteliefde gemeet word!

Ons wil hier nie verder spreek oor die intermenslike verhoudings binne die koninkryk van God nie. Ons wil ons graag bepaal by die Verbandsrelasies waarin die mens hom bevind: die verbandsrelasies met hulle eiesoortige strukture en hulle groot en byna onoorsienbare verskeidenheid. Om dit te kan doen moet ons kom tot 'n duidelike omskrywing van wat onder 'n verband verstaan word. Ook hier wil ons nie die verskillende standpunte soos ontwikkel deur die eeue heen krities bespreek nie, maar teties die eie standpunt stel. 'n Verband sien ons altyd as 'n verbinding van mense, maar dan kan die band wat die mense saambind verskillend wees. Hier het ons egter met 'n band wat saambind te doen, vandaar dat alle verbande 'n spesifieke karakter vertoon en noodwendig 'n gesagsrelasie bevat. Ons praat van die struktuur van die verband en sy struktuurprinsiepe. Omdat dit die geval is en daar verskillende bande is wat mense kan saambind, daarom is daar 'n groot verskeidenheid verbande. Sommige van hierdie verbande is direk deur God ingestel en omvat die menslike lewe vir die grootste gedeelte daarvan ongeag die persoonlike wil. Sodanige verbande noem ons institute, institutêre verbande. Daar bestaan egter ' $n$ groot menigte verbande wat nie direk deur God ingestel is nie en waaraan die mens kan 
behoort uit eie vrye wil vir solank as wat hy wil. Hierdie verbande het in die ontplooiing van die raadsplan van God ontstaan, is derhalwe deur God gewil maar nie direk deur Hom ingestel nie. Hier praat ons van in die ontplooiing van die raadsIlan van God nuutgedifferensieerde verbande. Maar ook hulle vertoon die struktuur van 'n verband en het 'n eie struktuurprinsiepe. Ook hier tref ons 'n ryke veelheid en verskeidenheid aan. Sommige van die verbande vertoon geen vorm van organisasie nie, ander, en hulle is by verre die meerderheid, vereis 'n hoë mate van organisasie. Met die skepping van Eva, is God die Insteller van die verbande en die Willer van 'n verbandslewe by die mens: dit is nie goed dat die mens alleen is nie! Vandaar dat die verbandslewe van die mens tot sy natuurlike lewe behoort. Wat hy van hierdie verbandslewe maak behoort tot die terrein van die kultuur. Tipies van die verbandslewe is egter dat in elke verband daar mense saamgebind word ten opsigte van 'n gemeenskaplike belang. Ons kan dit ook so stel: in die verbandslewe word die mense georganiseer ten opsigte van een of ander gemeenskaplike belang. Omdat dit ' $n$ gemeenskaplike belang is, daarom dui elke verband op 'n besondere aspek van die menslike lewe. So kan die mense georganiseer word ten opsigte van hulle geloofslewe en kry ons die kerk as samelewingsverband. Maar dan is hier slegs die geloofslewe van die mens op die spel en nie die totale mens nie. Die totale mens toon 'n rykheid van aspekte wat veel meer insluit as slegs sy geloofslewe.

Die mens kan ook georganiscer word ten opsigte van sy burgerlike lewe. Dit word gedoen in die staat as samelewingsverband. Maar ook dit omvat nie die totale mens nie, dit omvat slegs 'n gedeelte van die menslike lewe. Sy geloofslewe is alreeds hier uitgesluit. Die mens kan in 'n huweliksverband saamgesluit word. Ook hier is 'n hegte band wat die mense saambind, en hierdie band is nie die band van of kerk òf staat nie. Dit is iets anders, ' $n$ ander aspek van die menslike lewe. Die huweliksgemeenskap groei uit in die huisgesin sodra daar kinders vir die egpaar gebore word. Die gesinsverband vertoon 'n anderssoortigheid as kerk, staat of huwelik. Die gesinsverband word weer verbreed sodra die kinders in die huwelik tree, dan kry ons die familieverband. Maar die mense kan ook georganiseer word op die gebied van die kuns, die wetenskap, die sport met al sy vertakkings, in debatsverenigings, kultuurverenigings, ens., ens. En al hierdie verbande 
vertoon 'n eiesoortigheid wat van al die ander verskil. Ons kan 'n organisasie op die gebied van die ekonomie kry soos 'n handelsaak of bedryf of 'n maatskappy - dit is geen kerk of staat of huisgesin nie! So vertoon die mens 'n rykdom van aspekte waarin hy saamgebind kan word met ander mense en waar daar altyd 'n struktuur en struktuurprinsiepe aanwesig is, eiesoortig aan die bepaalde aspek waarin die mense saamgroepeer en georganiseer word. Een en dieselfde mens kan op hierdie wyse aan baie sodanige verbande behoort sonder dat daar ' $n$ tweespalt in sy lewe voorkom. Vandaar ons stelling dat geen enkele verband behalwe die koninkryk van God die hele of totale mens opeis nie. Elkeen organiseer die mens slegs ten opsigte van een aspek van sy lewe. En omdat dit die geval is, is die onderskeiding van Thomas van Aquino verkeerd as hy die saamlewe van mense opdeel in slegs twee verbande, $\mathrm{nl}$. kerk en staat. Later is deur ander kringe ook nog maatskappy hierby gevoeg. Ook dit laat nie reg geskied aan die ryke verskeidenheid wat God in die skepping en in die mens gelê het nie. Hier is wel deeglik kans vir reformasie, ook op die gebied van die terminologie - ook hier moet ons die benoembare goed benoem. So kan ons gerus maar ophou om te praat van Christelik-nasionaal, omdat daardeur slegs die kerk en staat van Thomas van Aquino tot sy reg kom. Ook kan ons gerus maar die term "maatskappy" laat vaar. So iets bestaan tog nie - die rykdom van verbande wat daaronder saamgegroepeer word, vertoon so 'n veelheid van andersoortigheid dat hulle beslis nie onder een noemer genoem kan word nie.

Waar ons nou 'n ryke verskeidenheid verbande aangetoon het en beklemtoon het dat dieselfde verbondeling in hulle almal ten opsigte van een of ander aspek van sy lewe 'n taak te vervul het, daar sal almal nou ook verstaan dat hierdie verbande nie geïsoleerd van mekaar kan bestaan nie. Ook kan hulle nie in disharmonie met mekaar bestaan nie. Dieselfde verbondeling speel in elkeen ' $n$ rol, hierdeur is die verbande al met mekaar verbind. En as hulle geïsoleerd van mekaar sou wees, sou die verbondeling 'n gebroke lewe moes lei. Maar die verbondeling staan in die koninkryk van God en die verbandslewe vertoon aspekte van die koninkryk. Isolasie is dus uitgesluit, en 'n intieme samehang van die verbande onderling met mekaar en van elkeen afsonderlik met die verbondeling is die ware toedrag van sake: ' $n$ interverbandsamehang so intiem dat dit eintlik nie begrypbaar is nie, 
kenmerk die verbandslewe. Hierdie intieme samehang het egter nie die eiesoortigheid op nie. Hierby moet nog die veelheid van eiesoortige verbande genoem word: ons kry baie kerke, state, huisgesinne, handelsmaatskappye, kunsvereniginge, ens. Maar elkeen binne die eiesoortige verbande vertoon dieselfde struktuur en struktuurprinsiepe: hulle word onderling van mekaar onderskei deur wat Dooyeweerd die subjektief-individuele identiteit noem. En hierdie subjektief-individuele identiteit van die een eiesoortige verband teenoor die ander verband van dieselfde soort val weer nie saam met die subjektiewe identiteit van al sy lede afsonderlik nie.

Met alles wat alreeds gesê is mag egter nooit vergeet word dat elke eiesoortige en in vergelyking met die ander, elke andersoortige samelewingsverband tog nogtans 'n saambinding van mense, van verbondelinge is nie. Die belangrikste konsekwensie hiervan is dat ons nie moet reken dat ons in die verbandslewe slegs met ' $n$ gedeeltelike of 'n gedeelde mens te doen het nie. Dit is wel waar dat die verband die mens organiseer ten opsigte van 'n bepaalde aspek van sy lewe. Tog is dit die mens wat in die verband staan, die volle mens met sy hele skeppingstoerusting. Vandaar die intieme samehang en harmonie tussen die verbande en die ongebrokenheid van die verbondeling in verbandslewe. Vandaar ook dat die een verband nie oor die ander mag heers nie maar dat elkeen slegs bevoegd is om op sy eie gebied reëlend op te tree. Dit is ook die rede waarom die kerk nie pligte aan sy lidmate mag oplê wat in stryd is met die Staat binne die koninkryk van God nie, d.w.s. met die pligte van die verbondeling binne die lewe van die Christelike staat nie. Die kerk mag nie die lewe van die staatsburger bemoeilik nie - die staat mag nie deur wetgewing die lidmaat van die kerk skaad nie - al die sameleuingsverbande het met dieselfde verbondeling te doen. So word die soewereiniteit in eie kring streng gehandhaaf, maar in samehang met die beginsel van universaliteit in eie kring. Daarby moet onthou word dat elke samelewingsverband aan dieselfde modaliteite deel het as wat hy die verbondeling onderskei kan word. Die struktuur van die verband hang af van die leidende en funderende modaliteite. Hierdeur kry elke verband sy eiesoortigheid en die leidende modaliteit tipeer ook die struktuur van die verband as sodanig. So vertoon alle samelewingsverbande die pisteutiese modaliteit maar slegs in die kerk is dit die kwalifiserende. Vandaar dat die pisteutiese 
funksie van die staat andersoortig is as dié van die kerk. Die staat se leidende modaliteit is die juridiese, dit bepaal die hele struktuur van die staat. Tog het ook die kerk en alle ander verbande ' $n$ juridiese funksie - vandaar dat kerkreg nooit ondergeskik behoort te wees aan staatsreg nie. Hulle is wel andersoortig. Daarom mag die staat nooit die kerkreg met staatsreg meet nie; daarom ook is ouerlike straf iets anders as die straf wat 'n magistraat oplê. In hierdie verband moet die aandag ook daarop gevestig word dat dit 'n verkeerde standpunt is as beweer word dat dit die taak van die staat is om alle reg vir alle verbande te positiveer, dat dit die taak van die kerk is om alle sake rakende die geloofsaspek vir alle ander verbande te reël, ens. Dit sou 'n skending van die eiesoortigheid van die funksies van die verbande t.o.v. hierdie aspekte in die lewes van sy verbondelinge binne die spesifieke verband inhou. Daarby sou dit 'n oorheersing van die een verband op die spesifieke terrein oor al die ander verbande verkondig! Van soewereiniteit in eie kring is daar dan eintlik geen sprake meer nie - dit is slegs 'n ander vorm van absolutisme! Die Christelike staat bestry die sonde onder sy onderdane op 'n eiesoortige wyse en bevorder op hierdie wyse die geloofslewe van sy onderdane en dra sy deel by tot die uitbreiding van die koninkryk van God. Waar hy sy plig hier versaak, kan die kerk vermanend optree. Net so kan die staat vermanend optree as die kerk sy plig versaak t.o.v. die burgerlikheid van sy lidmate. En dit geld vir alle verbande binne die koninkryk van God.

Graag vestig ons nog $u$ aandag op 'n aspek waaroor daar ook baie misverstand of verkeerde opvattinge bestaan, nl. die vryheid van die verbondeling en die vryheid van die verbandsmens. Soos reeds gestel bestaan die vryheid van die verbondeling daarin dat hy vrygemaak is van sonde tot gehoorsaming van die liefdeswet waardeur hy weer die beeld van sy Skepper vertoon. Maar hierdie verbondeling lewe in verband. Die vryheid van die verbande bestaan daarin dat die een verband nie oor die ander mag heers nie, nie reëlend inwerk op enige ander verband nie. Die verbande staan horisontaal langs mekaar en is gelykwaardig; die een is nie aan die ander gesubordineer nie maar elkeen is bevoegd om sy eie sake op die eiesoortige terrein te reël. Die verbondelinge is met ' $n$ spesifieke band binne elke verband saamgevoeg. Hierdie band bepaal die gesagstruktuur van die verband. So verskil die 
kerklike gesag van die gesinsgesag, van die staatsgesag, ens., ens. Elkeen is andersoortig kragtens die eiesoortigheid van die verband. Binne hierdie verband is die verbondeling vrywillig of kragtens die instituut gebonde aan die band wat hom daar bind. In sommige gevalle kan hy die verband verlaat, in ander, soos die huisgesin en die huwelik is die man en die vrou nie vry om die gemeenskap te verlaat nie, omdat die band van die instituut hulle omvat het. Die verbandsvryheid is dus iets anders as die vryheid van die verbondeling, maar e.g. is in laasgenoemde gegrond. Die vryheid van die verbande teenoor mekaar is gegrond in die skriftuurlike vryheid. Hiervan verskil weer die vryheid van die verbondeling binne die verbandslewe. Hier is die verbondeling onderwerp aan die struktuurprinsiepe van die verband, wat weer bepalend is vir die gesagstruktuur van die verband. In die kerk bind 'n gemeenskaplike geloofsbelydenis die verbondelinge saam onder die gesag van die kerkraad. Verbreek 'n lidmaat hierdie band van die gemeenskaplike geloofsbelydenis, is hy tugbaar. Hy kan hom aan die tug onderwerp, berou betoon en sy lidmaatskap in ere herstel, of hy kan hom verset teen die tug en hom blootstel aan uitsetting uit die kerk. Dieselfde is die geval met die burgerskap binne die soewereiniteit van die staat. Die vryheid van die burger word bepaal deur die struktuurprinsiepe van die verband. Maar selfs dit hef die vryheid van die verbondeling binne die koninkryk van God nie op nie. Trouens dit moet daarmee harmonieer net soos die verbandslewe met die verbondslewe moet harmonieer. Gebeur dit nie, word die verbondeling in twee geskeur en moet hy God meer gehoorsaam wees as die mens.

Pas ons hierdie siening i.v.m. vryheid toe op die aktuele probleem vandag in die wêreld, nl. persvryheid, dan moet in die eerste plek bepaal word of onder „pers" 'n eiesoortige sameleuingsverband verstaan word. Indien wel, moet 'n struktuuranalise daarvan moontlik wees en sal die struktuurprinsiepe daarvan ons 'n gesagsverhouding gee waaraan die vryheid gemeet kan word. Indien die pers geen eiesoortige samelewingsverband is nie, moet gevra word onder watter verband of verbande dit sorteer. As dit vasgestel is, sal die struktuurprinsiepe en gesagstruktuur van die verbande dadelik bepaal wat die vryheid van die pers omvat en sal alle grensoorskryding van hierdie spesifieke pers 'n oortreding wees op 'n ander verband se gebied en as ontoelaatbaar veroordeel moet word. 
In hierdie lig kry bv. ook die taak van 'n Publikasieraad vir Suid-Afrika nuwe perspektiewe, maar ook sake soos die geskryf oor die sluiting van swembaaie op Sondag deur die owerheid. Ons kan hieroor nog lank uitwei maar laat die saak hierby. Dit is duidelik genoeg vir elkeen om konsekwensies te trek. Ook hier word die verbondeling in sy verbandslewe deur die eisoortigheid van die band gebind tot gehoorsaming aan die tipiese van die verband, gesien die soewereiniteit in eie kring sowel as die universaliteit in eie kring van die verband: die vryheid in eie bevoegdheid en die universele samehang van die samelewingskringe met mekaar. Maar ook hier hef die vryheid in eie bevoegdheid van die samelewingsverband nie die vryheid van die verbondeling in die koninkryk van God op nie, is egter juis daarin gefundeer.

Die verbondeling lewe in hierdie bedeling in verbandslewe. Hierdie bedeling is egter alreeds binne die koninkryk van God Hierdie bedeling is egter van verbygaande aard. Die koninkryk van God duur egter tot in ewigheid. Wat sal nou die lewe van die verbondeling wees in die vervulde tyd, in die tyd na dic wederkoms van Christus op die wolke, wanneer die nuwe hemel sal neerdaal op die nuwe aarde? Miskien moet hieroor ten slotte 'n paar skrifmatige lyne getrek word.

\section{Die verbondeling as opstandeling:}

Die verbondeling as profeet, priester en koning is die kroon van God se skepping, sy plek is op die aarde en sy roeping is die beheersing van die aardse skepping tot eer en verheerliking van God. Hierdie heerskappy voer hy uit in gehoorsaming aan die wet van God, die liefdeswet, die struktuurwette en die positiewe wette. Hierdie mens sal die dood sterwe as hy die gebod oortree om nie van die vrugte van die boom wat in die middel van die tuin staan te eet nie. Die mens is ' $n$ onverganklike wese, anders ook hierin as alle ander geskape skepsele. Die mens word egter verlei en oortree die gebod. Hy raak nou algeheel verdorue en word met die dood gestraf. Die dood vernietig hom egter nie. Die opstanding uit die dood deur die verlossende genade word die mens toegesê: die genade kom tot die mens - verbeurde gunsbetoning deur die Vader. Die opstanding raak derhalwe alle mense, maar die ewige geluksalige lewe raak slegs die uitverkore volk van God. Die res sterf dic tweede dood na die oordeelsdag - gaan 
derhalwe die ewige verdoemenis in. Die opgestane mens bly egter mens, bly aardbewoner. Maar die uitverkore volk van God is nou deur sy Gees gereinig van die sonde, leef nou in ewige duurte in ' $n$ sondelose toestand. In hierdie lewe in ewige duurte staan die mens nog in 'n regstreekse verhouding tot God Drie-enig en lewe hy in 'n staat van voortdurende Godeverheerliking, iets wat ook in hierdie bedeling so moes wees maar wat vanueë die sonde altyd verduister is: „my beste werke is wegwerplik voor God". In die hiernamaals is die Vader-kind-, kind-Vader-relasie volmaak herstel.

Maar die reiniging van die sonde is volmaak volbring deur die Gees van God. Die mens in sy volle menslikheid staan nou in volle gehoorsaamheid in sy amp op die nuwe aarde: die aarde wat ook vroeër gesug het na verlossing maar nou ook herskape is. God staan derhalwe nou ook weer in volmaakte relasia tot die skepping: die Herskepper en herskape relasie. Ook die mens staan nou weer in die oorspronklike relasie tot die herskape skepping: tot stof, plant en dier. Ook wat hierdie deel van die skepping betref, is die oorspronklike relasie herstel: die wolf en die lam wei saam, en die boom dra sy vrug elke maand van die jaar. En Christus sal nie weer van die vrug van die wynstok gebruik voordat $\mathrm{Hy}$ weer gekom het nie! Gaan die mens hier voort met sy taakvervulling soos in sy taakopdrag van heers en beheers met die skepping gegee of gaan aan hom 'n nuwe opdrag gegee word? Alles dui daarop dat e.g. wel die geval gaan wees. Meer kan ons nie sê nie tensy ons wil spekuleer.

Staan die gereinigde verbondeling in die hiernamaals ook nog in verbandsrelasie tot sy mede-uitverkorene? In die hiernamaals sal daar nie in die huwelik uitgegee word nie. Ons kry daar dus nie nuwe huweliksluitinge nie, nie geboortes van kinders nie - ons leef daar in die vervulde tyd. Dit wil egter nie sê dat alle verbandsbande verbreek is nie: die genade werk ook deur die verbande heen - in die huidige bedeling ook deur die genetiese verband: straf werk tot in die derde en vierde geslag en die genade tot in die duisendste geslag. So praat ons van die toediening van die sakrament van die doop aan die verbondskind en van die uitverkore volk van God. So spreek die Skrif van volke en nasies en van konings onder die uitverkore volk van God in die lewe na hierdie bedeling.

Wat egter baie duidelik is in daardie lewe is die intermens- 
like relasie: ons is almal broeres van mekaar deur ons broerskap met Christus. Hierdie broerskap bind saam met bande so intiem dat daardeur volledige bevrediging aan alle aspekte van die mens gegee word. Onthou moet word dat ons in die vervulde tyd lewe en dat ons in die vervulde Raadsplan lewe die tyd van die ontplooiing is verby. So staan die verbondeling in volmaakte relasie nie alleen tot God nie maar ook tot die medeverbondeling en tot die herskape aarde in diens van sy Koning, tot sy eer en verheerliking binne die gekome ryk van God.

P.U. vir C.H.O.

J. A. L. Taljaard. 